\title{
Nutritional assessment of waste of cassava starch extraction dried in cattle feed
}

\section{Avaliação nutricional do resíduo da extração do amido da mandioca seco na alimentação de bovinos}

\author{
Tatiane Fernandes ${ }^{1 *}$; Maximiliane Alavarse Zambom²; Deise Dalazen Castagnara ${ }^{3}$; \\ Rodrigo Cezar dos Reis Tinini ${ }^{4}$; Eduardo Augusto da Cruz ${ }^{4}$; Everline Inês Eckstein ${ }^{4}$; \\ Maichel Jhonattas Lange ${ }^{1}$
}

\begin{abstract}
This study aimed to evaluate the digestive power of waste of cassava starch extraction dried (WCSEd) and corn, in addition to determining the appropriate level of WCSEd to replace corn in the diet of cattle. Studies to evaluate the in vitro digestibility and in situ degradability were performed. The study used four cattle with rumen cannula, individually fed with diets containing increasing levels $(0,33,66$ and $100 \%$ ) of WCSEd to replace corn, to evaluate the dry matter and nutrient intake and digestibility, $\mathrm{pH}$ and ammonia concentration of rumen fluid. The WCSEd showed differences in the in vitro digestibility of DM, OM and NDF $(P<0.05)$ compared to corn, but did not change the NDT and in situ degradability. As for in vivo reviews, the DM and nutrient intake was influenced by treatments in decreasing order, resulting in changes in the digestibility of DM, OM and NDT of diet, and a decreased concentration of $\mathrm{N}-\mathrm{NH}_{3}$, but the $\mathrm{pH}$ was not affected. The residue from the extraction of cassava starch showed lower in vitro digestibility; however, ruminal degradability did not differ from corn. Their use in ruminant feed reduces the intake and degradation of feed, but improves the use of $\mathrm{N}_{-} \mathrm{NH}_{3}$ in the rumen.
\end{abstract}

Key words: Degradability. Digestibility. Intake. Rumen parameters.

\section{Resumo}

Objetivou-se avaliar a degradabilidade potencial do REAMs e do milho e de determinar o nível adequado de REAMs, em substituição ao milho na ração de bovinos. Foram realizados estudos para avaliação da digestibilidade in vitro e degradabilidade in situ. Utilizou-se quatro bois castrados, canulados no rúmen, alimentados individualmente, com dietas contendo níveis crescentes $(0 \%, 33 \%, 66 \%$ e $100 \%)$ de REAMs em substituição ao milho, para avaliação da ingestão e digestibilidade da matéria seca e nutrientes, avaliação do $\mathrm{pH}$ e nitrogênio amoniacal do líquido ruminal. O REAMs apresentou diferenças quanto à digestibilidade in vitro da MS, MO e FDN $(P<0,05)$, quando comparado ao milho, mas não apresentou alteração quanto ao NDT e a degradabilidade in situ. Quanto às avaliações in vivo a ingestão de MS e dos nutrientes foi influenciada de forma decrescente pelos tratamentos, resultando em redução na digestibilidade da MS, MO e no NDT das dietas in vivo, ocorrendo redução na concentração de

\footnotetext{
${ }^{1}$ Discentes do curso de Mestrado em Zootecnia, Universidade Estadual do Oeste do Paraná, UNIOESTE, Marechal Cândido Rondon, PR, Brasil. E-mail: tati-_tati@hotmail.com; maichel_jl@hotmail.com

2 Prof., Centro de Ciências Agrárias, UNIOESTE, Marechal Cândido Rondon, PR, Brasil. E-mail: mazambom@hotmail.com

3 Prof ${ }^{\text {, }}$ Departamento de Medicina Veterinária, Universidade Federal do Pampa, UNIPAMPA, Uruguaiana, RG, Brasil. E-mail: deisecastagnara@yahoo.com.br

${ }^{4}$ Discentes do curso de Zootecnia, UNIOESTE, Marechal Cândido Rondon, PR, Brasil. E-mail: digotinini@hotmail.com; du.dacruz@hotmail.com, everline_eckstein@hotmail.com

* Author for correspondence
} 
N-NH3, mas o pH não foi influenciado. O resíduo da extração do amido da mandioca apresentou menor digestibilidade in vitro porem não diferiu do milho quanto a degradabilidade ruminal. Sua utilização na alimentação de ruminantes reduz a ingestão e degradação da ração, porém melhora o aproveitamento do N-NH3 no rúmen.

Palavras-chave: Degradabilidade. Digestibilidade. Ingestão. Parâmetros ruminais.

\section{Introduction}

The alternative foods may serve as a nutrient source for ruminants. However, they require frequent analysis regarding the nutritional composition (PEREIRA et al., 2008). It is important to know the characteristics of the feed, allowing the establishment of criteria for inclusion in animal feed (SOUZA et al., 2012).

The coproducts of cassava processing stand out as cheaper energy substitutes for feed formulation for ruminants (ZAMBOM et al., 2015; FERNANDES et al., 2015). This also enables the reduction of agribusiness waste, which would be discarded without treatment, resulting in damage to the environment (MELO et al., 2011).

The waste of cassava starch extraction dried (WCSEd) is obtained from the process used to extract starch from cassava by wetting and subsequently drying the co-product of this processing. According to Jasko et al. (2011), the moisture content of cassava bagasse exiting the process is often greater than $80 \%$, making it difficult to transport and store, as the material is highly perishable. However, drying this by-product can facilitate its use.

Although ruminants have the ruminal environment which enables the efficient use of different foods, this same environment can be significantly affected by changes in diet. Therefore, the adoption of practices such as the nutritional characterization of foods can be a tool to enable the use of coproducts in animal nutrition. As a result, the aim of this study was to assess the potential of WCSEd and the degradability of corn and to determine the appropriate level of WCSEd as a substitute for corn in the diet of cattle.

\section{Material and Methods}

The experiment was conducted at the Universidade Estadual do Oeste do Paraná UNIOESTE. The different foods used in the experiment were obtained 2013, sampled monthly for four months; corn (Dow 2B707) was produced at the UNIOESTE. The WCSEd was obtained from cassava processing industry, located in the city of Altônia-PR. The animal testing protocol was approved by the Ethics Committee on the use of Animals of UNIOESTE (49/13 Protocol).

The experimental design adopted for the evaluation of food, was completely randomized, with two treatments (WCSEd and ground grain corn) and four repetitions per treatment. Food samples to be evaluated were dried in an oven with forced air circulation to $55 \pm 5^{\circ} \mathrm{C}$ for 72 hours and ground using a mill with a $1 \mathrm{~mm}$ diameter sieve.

The levels of dry matter (DM), mineral matter (MM), crude protein (CP) and ether extract (EE) were determined according to methods described by AOAC (1990) and the determination of neutral detergent fiber (NDF) and acid detergent fiber (FDA) was performed according to Van Soest et al. (1991) (Table 1).

The carbohydrates were fractionated in A, B1, B2, and C as described by Sniffen et al. (1992). The percentage of total carbohydrates (TC) was obtained according to Sniffen et al. (1992). Fibrous carbohydrates (FC) were obtained from the NDF corrected to ashes and proteins (NDFcp); the NFC, corresponding to fractions $\mathrm{A}+\mathrm{B} 1$, indicated the difference between the TC and the NDFcp (HALL, 2003). Fraction B2 was obtained by the difference between the NDFcp and the $\mathrm{C}$ fraction, determined by the NDF indigestible (CABRAL et al., 2004), 
using 240 hours of in situ incubation. The crude protein was divided into five fractions: A, B1, B2,
B3 and $\mathrm{C}$, according to the method proposed by Licitra et al. (1996) (Table 1).

Table 1. Chemical composition of waste of cassava starch extraction dried (WCSEd), grain corn, soybean meal and corn silage.

\begin{tabular}{|c|c|c|c|c|}
\hline \multirow{2}{*}{ Composition } & \multicolumn{4}{|c|}{ Foods } \\
\hline & WCSEd & Corn & Soybean Meal & Corn Silage \\
\hline Dry Mater $\left(\mathrm{g} \mathrm{kg}^{-1}\right)$ & 869.07 & 880.00 & 886.68 & 307.41 \\
\hline Organic Mater ( $\mathrm{g} \mathrm{kg}^{-1}$ de DM) & 985.60 & 985.74 & 934.04 & 956.38 \\
\hline Crude Protein $\left(\mathrm{g} \mathrm{kg}^{-1} \text { de DM }\right)^{1}$ & 14.91 & 95.73 & 514.83 & 81.49 \\
\hline $\mathrm{A}\left(\mathrm{g} \mathrm{kg}^{-1}\right.$ de $\left.\mathrm{DM}\right)$ & 2.99 & 18.68 & 65.31 & 44.67 \\
\hline B1 $\left(\mathrm{g} \mathrm{kg}^{-1}\right.$ de DM $)$ & 1.06 & 3.49 & 22.44 & 6.12 \\
\hline B2 $\left(\mathrm{g} \mathrm{kg}^{-1}\right.$ de DM $)$ & 4.00 & 65.38 & 392.98 & 17.93 \\
\hline B3 $\left(\mathrm{g} \mathrm{kg}^{-1}\right.$ de DM $)$ & 2.35 & 1.90 & 31.92 & 3.89 \\
\hline $\mathrm{C}\left(\mathrm{g} \mathrm{kg}^{-1}\right.$ de $\left.\mathrm{DM}\right)$ & 4.51 & 6.28 & 2.18 & 8.88 \\
\hline Ether Extract ( $\mathrm{g} \mathrm{kg}^{-1}$ de DM) & 03.61 & 06.03 & 06.41 & 23.86 \\
\hline $\mathrm{NDN}\left(\mathrm{g} \mathrm{kg}^{-1} \text { de DM }\right)^{2}$ & 393.75 & 124.49 & 134.09 & 494.11 \\
\hline $\mathrm{ADF}\left(\mathrm{g} \mathrm{kg}^{-1} \text { de DM }\right)^{3}$ & 216.59 & 46.94 & 79.89 & 284.55 \\
\hline $\operatorname{NFC}\left(\mathrm{g} \mathrm{kg}^{-1} \text { de DM }\right)^{4}$ & 573.89 & 730.42 & 263.25 & 343.81 \\
\hline Total Carbohydrates $\left(\mathrm{g} \mathrm{kg}^{-1} \mathrm{de} \mathrm{DM}\right)^{5}$ & 967.64 & 854.91 & 397.34 & 837.92 \\
\hline $\mathrm{A}+\mathrm{B} 1\left(\mathrm{~g} \mathrm{~kg}^{-1}\right.$ de $\left.\mathrm{DM}\right)$ & 586.69 & 763.71 & 304.93 & 369.22 \\
\hline B2 $\left(\mathrm{g} \mathrm{kg}^{-1}\right.$ de DM $)$ & 303.32 & 76.32 & 71.55 & 294.86 \\
\hline $\mathrm{C}\left(\mathrm{g} \mathrm{kg}^{-1}\right.$ de $\left.\mathrm{DM}\right)$ & 77.63 & 14.88 & 20.86 & 173.84 \\
\hline
\end{tabular}

${ }^{1}$ Crude Protein Fractions, A: Soluble Fraction, B1: Fraction of rapid degradation, B2: Fraction of intermediate degradation, B3: Fraction of slow degradation, and C: indigestible Fraction; ${ }^{2} \mathrm{NDF}$ : Neutral Detergent Fiber; ${ }^{3} \mathrm{ADF}$ : Acid Detergent Fiber; ${ }^{4} \mathrm{CNF}$ : Non-fibrous carbohydrates; ${ }^{5} \mathrm{TC}$ : Total Carbohydrates Fractions, A + B1: Fraction of soluble carbohydrates and rapid degradable, B2: Potentially degradable Carbohydrates, C: Fraction of non-degradable carbohydrates.

Determination of in vitro dry matter digestibility (IVDMD) was performed using the technique described by Tilley and Terry (1963), adapted to the rumen, as described by Holden (1999). For the collection of ruminal fluid, we used three cattle, castrated males, fitted with a ruminal cannula. Then, $0.50 \mathrm{~g}$ of each food was weighed and placed in F57 filters (ANKON®). Two filters of each sample were packed into each jar, containing rumen fluid collected from different animals, plus buffer. The material was incubated for 48 hours with constant rotation at $39^{\circ} \mathrm{C}$. At the end of this period, $\mathrm{HCl}-$ Pepsin $(1: 10,000)$ solution was added, and the material was incubated for a further 24 hours. After incubation, DM and OM were determined.
The IVDMD and in vitro digestibility of organic matter (IVDOM) were calculated by calculating the difference between the amount incubated and the residue after incubation. Determination of in vitro digestibility of NDF (IVDNDF) adopted the methodology described by Goering and Van Soest (1975), by removing the filters with 48 hours of incubation, subjecting them to NSF analysis. The IVDNDF was calculated by the difference between the NDF incubated food and the NDF of the residue of incubation. IVDOM values were used to estimate the TDN, as described by Kunkle and Bates (1998).

For the realization of in situ degradability of DM and OM, samples of WCSEd and corn were milled 
with a $2 \mathrm{~mm}$ diameter sieve. For this, 7 grams of dry pre food was placed in each bag of nylon (10 x $20 \mathrm{~cm}$ ), providing 10 to $20 \mathrm{mg}$ of food per $\mathrm{cm}^{2}$ of useful area of the bag (NOCEK, 1988); this was performed in triplicate for each incubation time and per animal. Three rumen cannulated cattle were used, with an average body weight of $533 \pm 91.5 \mathrm{~kg}$, consuming $1.71 \pm 0.05 \%$ of BW. Incubation times were: $0,2,4,8,16,24$ and 48 hours (NRC, 2001); the average corn residue for these incubation times was $5.04 \pm 0.1,4.33 \pm 0.3,3.88 \pm 0.3,2.97 \pm 0.4$, $2.34 \pm 0.6,2.14 \pm 1.66 \pm 0.1$ and 0.6 , respectively, and the WCSEd was $5.14 \pm 0.2,3.92 \pm 0.3,2.83 \pm$ $0.3,1.94 \pm 0.4,1.55 \pm 0.5,1.33 \pm 0.95 \pm 0.1$ and 0.4 , respectively.

After incubation in situ, the bags went through the washing machine with constant renewal of the water until clear water appeared. After washing, the bags were dried in an oven with forced air ventilation to $55 \pm 5^{\circ} \mathrm{C}$ for 72 hours. The percentage degradation of $\mathrm{DM}$ and $\mathrm{OM}$ at each time was calculated by the amount that was left in the bag after incubation in the rumen. The nonlinear parameters $\mathrm{a}, \mathrm{b}$ and $\mathrm{c}$ were estimated via statistical analysis and genetic System, program (SAEG), developed by Universidade Federal de Viçosa (UFV, 2000). The effective degradability of dry matter (EDDM) and organic matter (EDOM) in the rumen was calculated using the equation described by Orskov and McDonald (1979), whereas the rate of passage of solids in the rumen of 2,5 and $8 \% / \mathrm{h}$ was calculated as suggested by ARC (1984) for low, medium and high rates of food intake. The data were subjected to analysis of variance and the differences were tested by Student's $t$ test to $5 \%$ probability using SAEG (UFV, 2000).
For in vivo assessments, four male bovines were used, which were Jersey breed, castrated, with a cannulated rumen, and an average body weight of $533 \pm 91.5 \mathrm{~kg}$. The animals were distributed in the experimental design in Latin square (4 x 4) with four treatments and four experimental periods of 21 days each, using 14 days for adaptation to diet and seven for data collection, making a total of 84 days. The treatments consisted of levels of WCSEd $(0 \%$, $33 \%, 66 \%$ and $100 \%$ ) instead of corn.

The diet was composed of $50 \%$ corn silage as a forage source, and 50\% concentrated feed (fine ground corn, WCSEd, soybean meal, bicalcium phosphate and mineral supplement), formulated according to the recommendations of the NRC (1996) to meet the requirements of the animals in maintenance, providing $2 \%$ of body weight (Table 2 ).

The animals remained confined in stalls, with an individual trough for the control of dry matter intake. The feeding was carried out twice a day, with $70 \%$ of the total daily DM offered at $6: 30 \mathrm{~h}$ and $30 \%$ at 16:30 h. During the seven days of each experimental period, the leftovers for each animal were weighed, and along with the samples of feed, were put in a freezer at $-20^{\circ} \mathrm{C}$.

For determination of the digestibility of dry matter and nutrients, from the 15 th to the 20th day, the fecal samples were collected directly in the rectal ampulla at 8:00, 10:00, 12:00, 14:00, 16:00 and 18:00 h every day. Fecal excretion estimates were obtained, using NDF indigestible (NDFi) as an internal indicator, as proposed by Waller et al. (1980). The NDFi was estimated by incubation in the rumen of the F57 ANKOM® filters Technology Corporation, for 240 hours (LIPPKE et al., 1986), with samples of food, leftovers and feces assessed by NDF analysis. 
Table 2. Ingredients and chemical composition of the rations, containing waste of cassava starch extraction dried (WCSEd) replacing the ground corn.

\begin{tabular}{|c|c|c|c|c|}
\hline \multirow{2}{*}{ Ingredients } & \multicolumn{4}{|c|}{ Replacement levels } \\
\hline & $0 \%$ & $33 \%$ & $66 \%$ & $100 \%$ \\
\hline Corn silage $\left(\mathrm{g} \mathrm{kg}^{-1}\right)$ & 500.00 & 500.00 & 500.00 & 500.00 \\
\hline WCSEd $\left(\mathrm{g} \mathrm{kg}^{-1}\right)$ & 0.00 & 119.13 & 226.96 & 320.07 \\
\hline Corn $\left(\mathrm{g} \mathrm{kg}^{-1}\right)$ & 376.22 & 237.76 & 109.96 & 0.00 \\
\hline Soybean Meal $\left(\mathrm{g} \mathrm{kg}^{-1}\right)$ & 110.94 & 131.17 & 150.52 & 166.55 \\
\hline Mineral Supplement ${ }^{1}\left(\mathrm{~g} \mathrm{~kg}^{-1}\right)$ & 11.27 & 9.02 & 8.96 & 8.92 \\
\hline Dicalcium Phosphate $\left(\mathrm{g} \mathrm{kg}^{-1}\right)$ & 1.57 & 2.93 & 3.58 & 4.46 \\
\hline \multicolumn{5}{|l|}{ Nutrients } \\
\hline Dry Matter $\left(\mathrm{g} \mathrm{kg}^{-1}\right)$ & 593.03 & 593.60 & 593.49 & 593.41 \\
\hline Organic Matter ( $\mathrm{g} \mathrm{kg}^{-1}$ of DM) & 952.32 & 950.11 & 947.00 & 946.83 \\
\hline Crude Protein ( $\mathrm{g} \mathrm{kg}^{-1}$ of DM) & 141.24 & 149.83 & 158.28 & 150.19 \\
\hline Ether Extract ( $\mathrm{g} \mathrm{kg}^{-1}$ of DM) & 15.78 & 14.87 & 14.58 & 14.33 \\
\hline Total Carbohydrates ( $\mathrm{g} \mathrm{kg}^{-1}$ of DM) & 791.94 & 794.46 & 792.14 & 796.68 \\
\hline $\mathrm{NDF}^{2}\left(\mathrm{~g} \mathrm{~kg}^{-1}\right.$ of DM$)$ & 325.05 & 343.24 & 365.44 & 390.20 \\
\hline $\mathrm{ADF}^{3}\left(\mathrm{~g} \mathrm{~kg}^{-1}\right.$ of $\left.\mathrm{DM}\right)$ & 183.72 & 199.00 & 209.64 & 225.85 \\
\hline TDN ${ }^{4}$ estimated ( $\mathrm{g} \mathrm{kg}^{-1}$ of DM) & 774.50 & 751.10 & 729.70 & 710.90 \\
\hline
\end{tabular}

${ }^{1}$ Composição Chemistry (kg- ${ }^{1}$ of product): Ca -260 g, P - 40 g, Co - 13 mg, Mg - 15 g, Mn - 1,100 mg, Zn - 3,000 mg, Se - 20 mg, I - 40 mg, S - 12 g, F - 170 mg e F - 400 mg (commercial product); ${ }^{2}$ NDF: Neutral Detergent Fiber; ${ }^{3}$ ADF: Acid Detergent Fiber; ${ }^{4} \mathrm{TDN}$ : Total Digestible Nutrients (Estimed by: TND= OM (\%)/100 [26,8 + 0,595 (IVDOM (\%))] ).

Samples of food, leftovers and feces were analyzed as to the levels of DM, ash, EE, CP, NDF, ADF, OM and TC. The TDN was estimated according to the equations described by Sniffen et al. (1992).

For the determination of $\mathrm{pH}$ and ammonia nitrogen $\left(\mathrm{N}-\mathrm{NH}_{3}\right.$ ), rumen fluid collection was performed on the 21 st day of each experimental period, via ruminal cannula, at the following times: 0, 2, 4, 6 and 8 hours after feeding in the morning. Immediately after collecting, the samples were filtered in cotton fabric and proceeded to the measurement of the $\mathrm{pH}$, using a digital potentiometer. A rate of $50 \mathrm{~mL}$ was added to $1 \mathrm{ml}$ of sulfuric acid (1:1) and frozen for the later determination of $\mathrm{N}-\mathrm{NH}_{3}$, as described by Fenner (1965).

For the values for ruminal parameters, plots subdivided by time analysis were used. For the variables concerning the intake of DM and nutrients, as well as in vivo digestibility, data were interpreted by analysis of variance using the SAEG (UFV,
2000), and submitted to polynomial regression, considering the levels of WCSEd $(0 \%, 33 \%, 66 \%$ or $100 \%$ ) at the $5 \%$ level of probability.

\section{Results and Discussion}

On in vitro digestibility of DM, OM, and NDF, the grain maize has higher digestibility (Table 3 ), closer to the values observed by Hashimoto et al. (2007), who reported 95.38\% for IVDMD values. This digestibility, as well as the IVDOM, is consistent with the fractionation of carbohydrates and nitrogen (Table 1); it should be noted that a small amount matches fraction $\mathrm{C}$, which is indigestible. The IVDMD of WCSEd was $88.92 \%$, differing statistically from corn, which is admittedly a high digestibility food, and is one of the most frequently used energy supplements in animal feed (RIBEIRO FILHO et al., 2012); however, it still has a high value of IVDMD, because it is a residue of the agro-industry. 
The NDF digestibility showed significant differences between food items tested, the grain maize showed a higher percentage of degradation of the NDF in comparison to the WCSEd ( $\mathrm{P}=0.047$ ). This can be explained by variation in the fractionation of carbohydrate (Table 1), where it can be observed that the corn showed a lower quantity of fraction B2 (8.93\%) compared to WCSEd (31.35\%). It can be observed that despite the high content of NDF and ADF and the fractionation of carbohydrate in WCSEd
(Table 1), this has the potential to be degraded in the rumen, and be used as an energy source in feed for ruminants, even showing a lower digestibility of corn. This high content of NDF and ADF is due to the extraction of starch during processing, resulting in concentration of the fibrous fraction of cassava (FELIPE et al., 2013). The WCSEd TDN showed no significant differences when compared to the grain corn, demonstrating its potential use in feeds for ruminants in place of maize.

Table 3. In vitro digestibility and degradability in situ waste of cassava starch extraction dried (WCSEd) and corn grain.

\begin{tabular}{|c|c|c|c|c|}
\hline & WCSEd & Corn & $\mathrm{SE}^{9}$ & $\mathrm{P}$ value \\
\hline & \multicolumn{4}{|c|}{ in vitro Digestibility } \\
\hline $\mathrm{DM}^{1} \%$ & 88.92 & 93.64 & 1.552 & 0.003 \\
\hline $\mathrm{OM}^{2} \%$ & 90.93 & 95.92 & 2.447 & 0.028 \\
\hline $\mathrm{NDF}^{3} \%$ & 81.52 & 84.88 & 1.219 & 0.047 \\
\hline \multirow[t]{2}{*}{$\mathrm{TDN}^{4} \%$} & 80.47 & 82.86 & 1.545 & 0.845 \\
\hline & \multicolumn{4}{|c|}{ in situ DM Degradability } \\
\hline$a^{5}$ & 24.145 & 24.684 & 1.059 & 0.831 \\
\hline$b^{6}$ & 70.066 & 81.602 & 5.096 & 0.306 \\
\hline$c^{7}$ & 0.146 & 0.067 & 0.026 & 0.131 \\
\hline $\mathrm{ED}^{8}(2 \%)$ & 84.782 & 83.929 & 0.602 & 0.541 \\
\hline $\mathrm{ED}(5 \%)$ & 74.890 & 67.712 & 2.273 & 0.117 \\
\hline \multirow[t]{2}{*}{$\mathrm{ED}(8 \%)$} & 67.929 & 58.738 & 2.905 & 0.116 \\
\hline & \multicolumn{4}{|c|}{ in situ OM Degradability } \\
\hline$a^{5}$ & 24.293 & 24.186 & 1.030 & 0.966 \\
\hline$b^{6}$ & 69.511 & 82.735 & 5.367 & 0.257 \\
\hline$c^{7}$ & 0.150 & 0.066 & 0.026 & 0.114 \\
\hline $\mathrm{ED}^{8}(2 \%)$ & 84.715 & 84.111 & 0.630 & 0.684 \\
\hline $\mathrm{ED}(5 \%)$ & 75.074 & 67.635 & 2.358 & 0.117 \\
\hline $\mathrm{ED}(8 \%)$ & 68.230 & 58.542 & 3.018 & 0.108 \\
\hline
\end{tabular}

Values in the same row, followed by letters differ by analysis of variance at $5 \%$ of significance.

${ }^{1} \mathrm{DM}$ : Dry Matter; ${ }^{2} \mathrm{OM}$ : Organic Matter; ${ }^{3} \mathrm{NDF}$ : Neutral Detergent Fiber; ${ }^{4} \mathrm{TDN}$ : Total Digestible Nutrients; ${ }^{5} \mathrm{~A}$ : Fraction of rapid degradation; ${ }^{6} \mathrm{~B}$ : Potentially degradable fraction; ${ }^{7} \mathrm{C}$ : Constant rate of degradation of fraction B; ${ }^{8} \mathrm{ED}$ : Effective Degradability in different rates of passage (2, 5 and 8\%); ${ }^{9} \mathrm{SE}$ : Standard Error.

The parameters ' $a$ ', 'b' and 'c' of DM and OM and the DMDEG and OMDEG, for rates of $2 \%$, $5 \%$ and $8 \%$, did not present significant differences between WCSEd and corn (Table 3), indicating that WCSEd can be an alternative to the use of corn in feed for ruminants, as it is as efficient as corn in the supply of energy to the ruminal microorganisms.

The WCSEd presented a fraction that was $24.15 \%$ lower than that observed by Martins et al. (1999), who assessed the degradability of the 
MS of the zest of cassava, obtaining a result of $55.6 \%$. These differences are due to the higher starch content, present in the cassava zest, once the WCSEd is subjected to the starch extraction process. However, the values of DMDEG in $2 \%$, $5 \%$ and $8 \%$ obtained in this study were similar to those seen by the same authors: $81.9 \%, 75.0 \%$ and $71.4 \%$, respectively.

For DMDEG, values higher than those observed by Cação et al. (2012) were obtained, of $66.0 \%$, $50.9 \%$ and $43.4 \%$ for the same rates of passage. With increased passage rate for the reduction of degradation of both food and corn there is increased susceptibility to degradation, with an increased rate of passage, as a function of the WCSEd presenting a numerically higher degradation rate than corn.
The WCSEd and maize did not show any differences ( $P \geq 0.05$ ) for the OMDEG. For corn, the values obtained were higher than those observed by Fortaleza et al. (2009), which were $51.81 \%$ and $46.84 \%$ and the rates were $5 \%$ and $8 \%$.

Dry matter intake was influenced in descending order, by increasing the level of WCSEd in place of maize (Table 4). These results corroborate with those presented by Fernandes et al. (2015), in which cows fed with corn-based animal feed showed a higher intake of $10.27 \%$ compared to those that were fed with rations based on WCSEd. The reduction of intake may be associated with increased levels of NDF in diet, since the period for feeding the animals was limited to 8 hours a day, increasing the effect of NDF on ingestion (SILVA, 2011).

Table 4. Daily intake and apparent digestibility of dry matter and nutrients of cattle, receiving diets containing waste of cassava starch extraction dried (WCSEd) replacing the feed corn.

\begin{tabular}{|c|c|c|c|c|c|c|c|c|}
\hline & \multicolumn{4}{|c|}{ Replacement levels } & \multirow{2}{*}{$\begin{array}{c}\text { Regression } \\
\text { Equation }\end{array}$} & \multirow{2}{*}{$\mathrm{SE}^{16}$} & \multicolumn{2}{|c|}{ P value } \\
\hline & $0 \%$ & $33 \%$ & $66 \%$ & $100 \%$ & & & $\mathrm{~L}$ & $\mathrm{Q}$ \\
\hline $\operatorname{DMI}^{1}\left(\mathrm{~kg} \operatorname{dia}^{-1}\right)$ & 9.75 & 9.40 & 9.45 & 8.98 & 1 & 0.426 & 0.0177 & 0.7338 \\
\hline DMI (\%PV) & 1.76 & 1.69 & 1.76 & 1.65 & $\hat{\mathrm{Y}}=1.714$ & 0.030 & 0.2151 & 0.6355 \\
\hline $\mathrm{OMI}^{2}\left(\mathrm{~kg} \mathrm{dia}^{-1}\right)$ & 9.28 & 8.93 & 8.94 & 8.50 & 2 & 0.406 & 0.0146 & 0.7817 \\
\hline $\mathrm{CPI}^{3}\left(\mathrm{~kg} \mathrm{dia}^{-1}\right)$ & 1.42 & 1.48 & 1.55 & 1.39 & 3 & 0.067 & 0.9758 & 0.0065 \\
\hline $\mathrm{EEI}^{4}\left(\mathrm{~kg} \mathrm{dia}^{-1}\right)$ & 0.27 & 0.23 & 0.21 & 0.18 & 4 & 0.022 & 0.0048 & 0.6766 \\
\hline $\mathrm{TCI}^{5}\left(\mathrm{~kg} \mathrm{dia}^{-1}\right)$ & 7.67 & 7.43 & 7.44 & 7.15 & 5 & 0.331 & 0.0278 & 0.8132 \\
\hline $\operatorname{NDFI}^{6}\left(\mathrm{~kg} \mathrm{dia}^{-1}\right)$ & 3.06 & 2.98 & 3.28 & 3.37 & 6 & 0.153 & 0.0495 & 0.4882 \\
\hline $\mathrm{ADFI}^{7}\left(\mathrm{~kg} \mathrm{dia}^{-1}\right)$ & 1.74 & 1.81 & 1.90 & 1.99 & 7 & 0.096 & 0.0013 & 0.8749 \\
\hline $\mathrm{DMD}^{8}(\%)$ & 69.24 & 68.01 & 66.91 & 59.28 & 8 & 1.346 & 0.0288 & 0.2398 \\
\hline $\mathrm{OMD}^{9}(\%)$ & 73.07 & 72.52 & 71.58 & 64.94 & 9 & 1.219 & 0.0320 & 0.1907 \\
\hline $\mathrm{CPD}^{10}(\%)$ & 70.60 & 71.43 & 71.47 & 61.66 & $\hat{\mathrm{Y}}=68.789$ & 1.552 & 0.1107 & 0.1517 \\
\hline $\operatorname{EED}^{11}(\%)$ & 79.72 & 74.51 & 76.88 & 70.26 & $\hat{Y}=75.342$ & 1.681 & 0.0780 & 0.8073 \\
\hline $\mathrm{TCD}^{12}(\%)$ & 73.55 & 73.43 & 72.50 & 66.50 & 12 & 1.150 & 0.0383 & 0.1710 \\
\hline $\operatorname{NDFD}^{13}(\%)$ & 48.72 & 42.02 & 49.33 & 38.09 & $\hat{\mathrm{Y}}=44.541$ & 2.171 & 0.4047 & 0.4321 \\
\hline $\operatorname{ADFD}^{14}(\%)$ & 43.41 & 45.95 & 52.49 & 41.38 & $\hat{Y}=45.806$ & 2.309 & 0.2225 & 0.3264 \\
\hline $\mathrm{TDN}^{15}(\%)$ & 73.05 & 73.33 & 72.73 & 65.79 & 15 & 1.1783 & 0.0494 & 0.1306 \\
\hline
\end{tabular}

${ }^{1,2} \mathrm{DMI}$ : Dry Matter Intake; ${ }^{2} \mathrm{OMI}$ : Organic Matter Intake; ${ }^{3} \mathrm{CPI}$ : Crude Protein Intake; ${ }^{4} \mathrm{EEI}$ : Ether Extract Intake; ${ }^{5} \mathrm{TCI}:$ Total Carbohydrate Intake; ${ }^{6}$ NDFI: Neutral Detergent Fiber Intake; ${ }^{7}$ ADFI: Acid Detergent Fiber Intake; 8DMD: Dry Matter Digestibility; ${ }^{9}$ OMD: Organic Matter Digestibility; ${ }^{10} \mathrm{CPD}$ : Crude Protein Digestibility; ${ }^{11}$ EED: Ether Extract Digestibility; ${ }^{12} \mathrm{TCD}$ : Total Carbohydrate Digestibility; ${ }^{13}$ NDFD: Neutral Detergent Fiber Digestibility; ${ }^{14}$ ADFD: Acid Detergent Fiber Digestibility; ${ }^{15}$ TDN: Total Digestible Nutrients; ${ }^{16} \mathrm{SE}$ : Standard Error.

${ }^{1} \hat{\mathrm{Y}}=9.72737-0.00672802 \mathrm{x}\left(\mathrm{R}^{2}=0.85\right) ;{ }^{2} \hat{\mathrm{Y}}=9.25919-0.00700936 \mathrm{x}\left(\mathrm{R}^{2}=0.89\right) ;{ }^{3} \hat{\mathrm{Y}}=1.40716+0.00487148 \mathrm{x}-0.0000487491 \mathrm{x}^{2}\left(\mathrm{R}^{2}=\right.$ $0.79) ;{ }^{4} \hat{\mathrm{Y}}=0.261268-0.000793626 \mathrm{x}\left(\mathrm{R}^{2}=0.98\right) ;{ }^{5} \hat{\mathrm{Y}}=7.65297-0.00465462 \mathrm{x}\left(\mathrm{R}^{2}=0.88\right)$

${ }^{6} \hat{\mathrm{Y}}=2.98694+0.00373408\left(\mathrm{R}^{2}=0.76\right) ;{ }^{7} \hat{\mathrm{Y}}=1.73492+0.0024833 \mathrm{x}\left(\mathrm{R}^{2}=0.80\right) ;{ }^{8} \hat{\mathrm{Y}}=70.5044-0.0933549 \mathrm{x}\left(\mathrm{R}^{2}=0.80\right) ;{ }^{9} \hat{\mathrm{Y}}=74.3284-$ $0.0764213 \times\left(R^{2}=0.76\right) ;{ }^{12} \hat{Y}=71.49586-0.06662044 x\left(R^{2}=0.73\right) ;{ }^{15} \hat{Y}=74.5911-0.0676469\left(R^{2}=0.64\right)$. 
The DM intake as a percentage of BW was not influenced by diet, corroborating with the effects observed by Fernandes et al. (2015), using the wet residue of cassava in place of maize, in the feeding of lactating cows. The animals showed no weight gain throughout the experiment.

The intake of OM and EE decreased linearly with increasing substitution of corn for WCSEd. This variation is due to the variation observed for the intake of DM. In the ingestion of CP, quadratic variation was observed, while for NDF and ADF, an increase was observed $(\mathrm{P} \leq 0.05)$ as a result of the levels of these nutrients in WCSEd, in response to increasing levels of WCSEd in the diet (Table 2).

The digestibility coefficients of DM, OM and TC, as well as TDN, were influenced $(\mathrm{P} \leq 0.05)$ by an increase in WCSEd in place of maize. However, the other nutrients were not influenced by the treatments $(P \geq 0.05)$. There was a reduction in the coefficient of digestibility of DM, and, consequently, reduced digestibility coefficient of OM and TC. The values observed in this study are similar to those obtained in a study evaluating the substitution of corn for wet residue of cassava $(0 \%, 25 \%, 50 \%, 75 \%$ and $100 \%$ ) in the diet of lactating cows (ZAMBOM et al., 2015), obtaining mean values of $65.42 \%$ for IVDMD.

In this study, an increase in the content of NDF and ADF in feed (Table 2) was observed due to the greater concentration of these nutrients in WCSEd, and lower digestibility of NDF from WCSED in comparison to corn (Table 3) which may have influenced the reduction of digestibilities of DM and OM, causing a decrease in TDN of the feed with the increased levels of replacement of WCSEd, since TDN is influenced by DM and digestibility of $\mathrm{OM}$ and reduces with the increase in levels of NDF (BERCHIELLI et al., 2011).

No difference $(P \geq 0.05)$ between the NDF digestibility in experimental rations was obtained, corroborating the absence of ruminal $\mathrm{pH}$ change between treatments (Figure 1). According to Kozloski (2016), NDF digestibility can be influenced by changes in rumen $\mathrm{pH}$, reducing the grip to fiber, and modification of microbial metabolism, when there is an excessive reduction in the rumen $\mathrm{pH}$.

Figure 1. Concentration of (a) $\mathrm{pH}$ and (b) ammonia nitrogen (NH3-N) in the rumen liquid of bovine animals receiving diets containing waste of cassava starch extraction dried (WCSEd) replacing the feed corn during the hours after feeding.
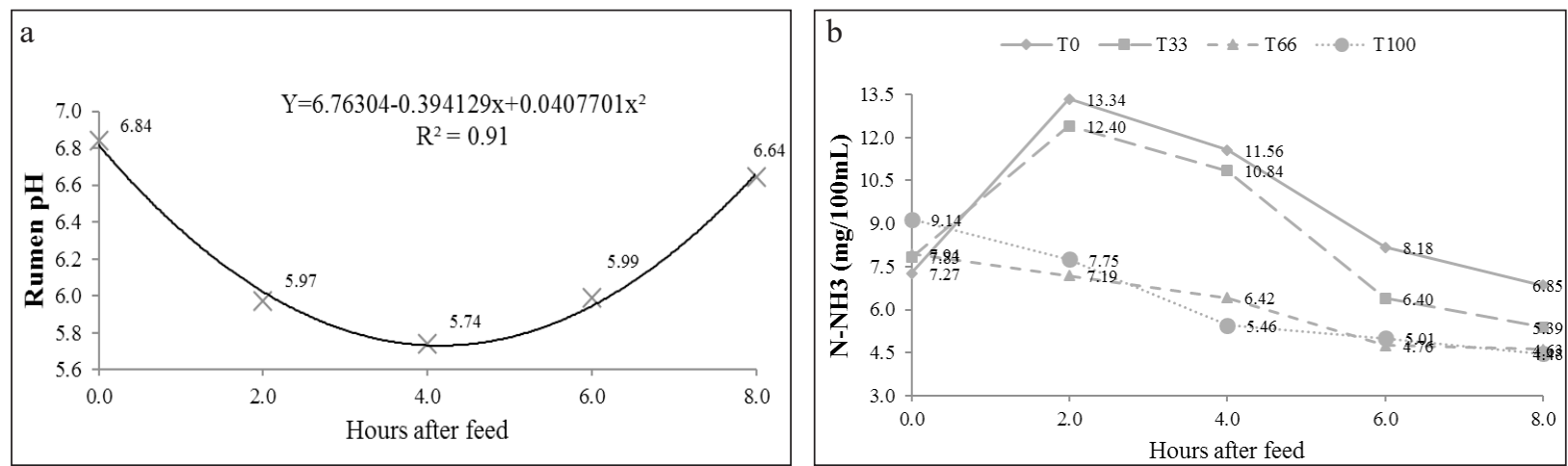

- T0: $\hat{\mathrm{Y}}=8.30059+2.0399 \mathrm{x}-0.292536 \mathrm{x}^{2}\left(\mathrm{R}^{2}=0.70\right)$; 口 T33: $\hat{\mathrm{Y}}=8.7399+1.46432 \mathrm{x}-0.2511 \mathrm{x}^{2}\left(\mathrm{R}^{2}=0.74\right) ; \bullet \mathrm{T} 100: \hat{\mathrm{Y}}=8.78044-$ $0.603697 x\left(R^{2}=0.92\right)$.

For the ruminal $\mathrm{pH}$, no interaction was observed between treatments and hours after feeding, as variation only occurred for the hours after feeding, thus obtaining a minimum $\mathrm{pH}$ of $4.83,4: 50$ hours 
after feeding. The use of WCSEd, substituting corn, made the maintenance of an adequate, ruminal environment possible once the ruminal bacteria are adapted to maintain its growth in this medium with varying $\mathrm{pH}$ of 5.5 to 7.0 (BERCHIELLI et al., 2011).

A significant interaction was observed between the hours after feeding, and the treatments for $\mathrm{NH}_{3}-\mathrm{N}$ levels. A significant effect was observed between treatments at 2 hours $(\hat{\mathrm{Y}}=13.75038-0$, $782854 x ; R 2=0.81)$ and 4 hours $(\hat{Y}=11.9605-0$, $0681741 \mathrm{x} ; \mathrm{R} 2=0.91)$ after feeding, decreasing with the increased levels of WCSEd in the substitution. According to Santos and Pedroso (2011), the pool of $\mathrm{NH}_{3}-\mathrm{N}$ tends to increase between 2 and 4 hours after feeding, depending on the degradability of crude protein in the diet and the conditions for growth of the microbiota.

For $0 \%$ and $33 \%$ treatments for the replacement of corn for WCSEd, the maximum values of $\mathrm{NH}_{3}-\mathrm{N}$ occurred at $3.48(3: 29)$ and $2.92(2: 55)$ hours, respectively, after feeding, corroborating with the results, obtained by Zeoula et al. (2002), who obtained a higher quantity of $\mathrm{NH}_{3}-\mathrm{N}(12.5 \mathrm{mg} / 100$ ml) 2 hours after feeding; this treatment contained corn, and was compared to the treatment of cassava with chips in the feed.

Using $66 \%$ substitution, no significant variation was observed $(\mathrm{P} \geq 0.05)$ during the hours after feeding, while for the treatment with $100 \%$ substitution, an effect was observed $(\mathrm{P} \leq 0.05)$, descending linearly in the concentration of ruminal liquid $\mathrm{NH}_{3}-\mathrm{N}$, which lowered as more WCSEd was added to the feed.

It is possible that the low concentrations of $\mathrm{NH}_{3}-\mathrm{N}$ observed for these treatments, as a result of the increased microbial synthesis and depending on the need for increased isoproteic maintenance of soybean meal diets, along with the increased levels of WCSEd in the diet (Table 1 and 2), may have caused a reduction in the number of protozoa as a function of the greatest amount of EE from the soybean meal. This may have led to a higher consumption of $\mathrm{NH}_{3}-\mathrm{N}$ by ruminal bacteria (MARTINELE et al., 2008), as protozoa ingest bacteria as the main source of amino acids and nucleic acids (KOZLOSKI, 2016).

\section{Conclusions}

The residue of cassava starch extraction showed lower in vitro digestibility but did not differ from the corn with regard to rumen degradability. Their use in ruminant feed reduces feed intake and degradation, but improves the use of $\mathrm{NH}_{3}-\mathrm{N}$ in the rumen.

\section{References}

AGRICULTURAL RESEARCH COUNCIL - ARC. The nutrient requirements for ruminant livestock. London: CAB. 1984. 45 p. Supplement 1.

ASSOCIATION OF OFFICIAL ANALYTICAL CHEMISTS - AOAC. Official methods of analysis. $16^{\text {th }}$ ed. Arlington: AOAC Internacional, 1990. 1025 p.

BERCHIELLI, T. T.; PIREZ, A. V.; OLIVEIRA, S. G. Nutrição de ruminantes. 2. ed. Jaboticabal: Funep, 2011. $616 \mathrm{p}$.

CABRAL, L. S.; VALADARES FILHO, S. C.; DETMANN, E.; ZERVOUDAKIS, J. A.; VELOSO, R. G.; NUNES, P. M. M. Taxas de digestão das $f$ rações proteicas e de carboidratos para as silagens de milho e de capim-elefante, o feno de capim-tifiton-85 e o farelo de soja. Revista Brasileira de Zootecnia, Viçosa, MG, v. 33, n. 6, p. 1573-1580, 2004.

CAÇÃO, M. M. F.; COSTA, C.; MEIRELLES, P. R. L.; EZEQUIEL, J. M. B.; GALATI, R. L.; SILVA, M. G. B. Degradabilidade ruminal da matéria seca de grãos de milho e de sorgo com alto ou baixo conteúdo de tanino processados. Revista Brasileira de Saúde e Produção Animal, Salvador, v. 13, n. 2, p. 516-528, 2012.

FELIPE, F. I.; ALVES, L. R. A.; VIEIRA, R. M. Fécula de mandioca, produção na Tailândia versus Brasil. Piracicaba: Mercado \& Negócios, Agroanalysis, 2013. 1 p.

FENNER, H. Method for determining total volatile bases in rumen fluid by steam distillation. Journal Dairy of Science, Philadelphia, v. 48, n. 2, p. 249-251, 1965. 
FERNANDES, T.; ZAMBOM, M. Z.; CASTAGNARA, D. D.; SOUZA, L. C.; DAMASCENO, D. O.; SCHMIDT, E. L. Use of dried waste of cassava starch extraction for feeding lactating cows. Anais da Academia Brasileira de Ciências, Rio de Janeiro, v. 87, n. 2, p. 1101-1111, 2015.

FORTALEZA, A. P. S.; SILVA, L. D. F.; RIBEIRO, E. L. A.; BARBERO, R. P.; JÚNIOR, F. L. M.; SANTOS, A. X.; CASTRO, V. S.; CASTRO, F. A. B. Degradabilidade ruminal In Situ dos componentes nutritivos de alguns suplementos concentrados usados na alimentação de bovinos. Semina: Ciências Agrárias, Londrina, v. 30, n. 2, p. 481-496, 2009.

GOERING, H. K.; VAN SOEST, P. J. Forage fiber analyses (apparatus, regents, procedures, and some aplications). Washington: United States Department of Agriculture, 1975. 20 p. (Agriculture Handbook, 379).

HALL, M. B. Challenges with nonfiber carbohydrate methods. Journal of Animal Science, Champaign, v. 81, n. 12, p. 3226-3232, 2003.

HASHIMOTO, J. H.; ALCALDE, C. R.; ZAMBOM, M. A.; SILVA, K. T.; MACEDO, F. A. F.; MARTINS, E. N.; RAMOS, C.E. C. O.; PASSIANOTO, G. O. Desempenho e digestibilidade aparente em cabritos Boer x Saanen em confinamento recebendo rações com casca do grão de soja em substituição ao milho. Revista Brasileira de Zootecnia, Viçosa, MG, v. 36, n. 1, p. 174-182, 2007.

HOLDEN, L. A. Comparison of methods of in vitro matter digestibility for tem feeds. Journal of Dairy Science, Philadelphia, v. 2, n. 8, p. 1791-1794, 1999.

JASKO, A. C.; ANDRADE, J.; CAMPOS, P. F.; PADILHA, L.; PAULI, R.B.D.; QUAST, L. Caracterização físico-química de bagaço de mandioca in natura e após tratamento hidrolítico. Revista Brasileira de Tecnologia Agroindustrial, Curitiba, v. 5, p. 427-441, 2011. Suplemento.

KOZLOSKI, G. W. Bioquímica dos ruminantes. 3. ed. rev. e ampl. Santa Maria: Ed. da UFSM, 2016. 216 p.

KUNKLE, W. E; BATES, D. B. Evaluating feed purchasing options: energy, protein, and mineral supplements. In: FLORIDA BEEF CATTLE SHORT COURSE, 1998, Gainesville. Proceedings... Gainesville: University of Florida, 1998. p. 59-70.

LICITRA, G.; HERNANDEZ, T. M.; VAN SOEST, P. J. Standardization of procedures for nitrogen fractionation of ruminant feed. Animal Feed Science and Technology, Ithaca, v. 57, n. 4, p. 347-358, 1996.

LIPPKE, H.; ELLIS, W. C.; JACOBS, F. Recovery of indigestible fiber from feces of sheep and cattle on forage diets. Journal of Dairy Science, Philadelphia, v. 69, n. 2, p. 403-412, 1986.
MARTINELE, I.; EIFERT, E. C.; LANA, R. P.; ARCURI, P. B.; D’AGOSTO, M. Efeito da monensina e do óleo de soja sobre os protozoários ciliados do rúmen e correlação dos protozoários com parâmetros da fermentação ruminal e digestivos. Revista Brasileira de Zootecnia, Viçosa, MG, v. 37, n. 6, p. 1129-1136, 2008.

MARTINS, A. S.; ZEOULA, L. M.; PRADO, I. N.; MARTINS, E. N.; LOYOLA, V. R. Degradabilidade ruminal in situ da matéria seca e proteína bruta das silagens de milho e sorgo e de alguns alimentos concentrados. Revista Brasileira de Zootecnia, Viçosa, MG, v. 28, n. 5, p. 1109-1117, 1999.

MELO, P. S.; BERGAMASCHI, K. B.; TIVERON, A. P.; MASSARIOLI, A. P.; OLDONI, T. L.C.; ZANUS, M. C.; PEREIRA, G. E.; ALENCAR, S. M. Composição fenólica e atividade antioxidante de resíduos agroindustriais. Ciência Rural, Santa Maria, v. 41, n. 6, p. 1088-1093, 2011.

NATIONAL RESEARCH COUNCIL - NRC. Nutrient requirements of beef cattle. $7^{\text {th }}$ ed. Washington, D.C.: National Academy Press, 1996. 232 p.

$7^{\text {th }}$ ed. Washington, D.C: National

Academy Press, 2001. 381 p.

NOCEK, J. In situ and other methods to estimate ruminal protein and energy digestibility: a review. Journal of Dairy Science, Philadelphia, v. 71, n. 8, p. 2051-2069, 1988.

ORSKOV, E. R.; MCDONALD, I. The estimation of protein degradability in the rumen from incubation measurements weighted according to rate of passage. The Journal of Agricultural Science, Toronto, v. 92, n. 2, p. 499-503, 1979.

PEREIRA, E. S.; REGADAS FILHO, J. G. L.; ARRUDA, A. M. V.; MIZUBUTI, I. Y.; VILLARROE, A. B. S.; PIMENTEL, P. G.; CÂNDIDO, M. J. D. Equações do NRC (2001) para predição do valor energético de coprodutos da agroindústria no nordeste brasileiro. Revista Brasileira de Saúde e Produção Animal, Salvador, v. 9, n. 2, p. 258-269, 2008.

RIBEIRO FILHO, H. M. N. Estratégias para o manejo dos animais e do pasto em sistemas de produção de leite. Veterinária, Montevideo, v. 48, p. 91-96, 2012. Suplemento 1.

SANTOS, F. A. P.; PEDROSO, A. M. Metabolismo de proteínas. In: BERCHIELLI, T. T.; PIREZ, A. V.; OLIVEIRA, S. G. Nutrição de ruminantes. 2. ed. Jaboticabal: Funep, 2011. 616 p.

SILVA, J. F. C. Mecanismos reguladores de consumo. In: BERCHIELLI, T. T.; PIREZ, A. V.; OLIVEIRA, S. G. Nutrição de ruminantes. 2. ed. Jaboticabal: Funep, 2011. $616 \mathrm{p}$. 
SNIFFEN, C. J.; O’CONNOR, J. D.; VAN SOEST, P. J.; FOX, D. G.; RUSSELL, J. B. A net carbohydrate and protein system for evaluating cattle diets: II. Carbohydrate and protein availability. Journal of Animal Science, Champaign, v. 70, n. 11, p. 3562-3577, 1992.

SOUZA, L. C.; ZAMBOM, M. A.; POZZA, M. S. S.; NERES, M. A.; RADIS, A. C.; BORSATTI, L.; CASTAGNARA, D. D.; GUNDT, S. Development of microorganisms during storage of wet brewery waste under aerobic and anaerobic conditions. Revista Brasileira de Zootecnia, Viçosa, MG, v. 41, n. 1, p. 188193, 2012.

TILLEY, J. M. A.; TERRY, R. A. A two stage technique for the in vitro digestion of forage crops. Grass and Forage Science, Malden, v. 18, n. 2, p. 104-111, 1963.

UNIERSIDADE FEDERAL DE VIÇOSA - UFV. Sistema de análises estatísticas e genéticas - SAEG. Versão 8.0. Viçosa, MG: UFV, 2000. 142 p.
VAN SOEST, P. J.; ROBERTSON, J. B.; LEWIS, B. A. Carbohydrate metodology, metabolism, and nutritional implications in dairy cattle. Journal of Dairy Science, Philadelphia, v. 74, n. 10, p. 3583-3597, 1991.

WALLER, J.; MERCHEN, N.; HANSON, T. KLOPFENSTEIN T. Effect of sampling intervals and digesta markers on abomasal flow determinations. Journal of Animal Science, Champaign, v. 50, n. 6, p. 1122-1126, 1980.

ZAMBOM, M. A.; FERNANDES, T.; SOARES, M. S. S. P.; CASTAGNARA, D. D.; NERES, M. A.; JAVORSKI, C. R.; CRUZ, E. A. Características da silagem de resíduo úmido de fécula de mandioca adicionada de níveis de ureia. Archivos de Zootecnia, Córdoba, v. 63, n. 244, p. 677- 688, 2015.

ZEOULA, L. M.; CALDAS NETO, S. F.; BRANCO, A. F.; PRADO, I. N.; DALPONTE, A. O.; KASSIES, M.; FREGADOLLI, F. L. Mandioca e resíduos das farinheiras na alimentação de ruminantes: $\mathrm{pH}$, concentração de amônia e eficiência microbiana. Revista Brasileira de Zootecnia, Viçosa, MG, v. 31, n. 3, p. 1582-1593, 2002. 
